\title{
OFFICIAL REPORTS OF SOCIETIES
}

\author{
IX OBARG OP \\ MARY E. THORNTON
}

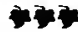

(We must ask contributors to this department to make their reports as concise as posaible, omitting all mention of regular routine business, and stating such facts as are of special interest to absent members or to the profession at large. Tbe JourNAL has aiready increased it regular reading pages from sixty-four to eights, and it must keep within these limits for at least the remainder of the present year. In order to do this all of the departments are being condensed to make room for our constantly increasing ltems of interest.-ED.]
\end{abstract}

\section{THE NURgES' AgSOCIATED ALUMN}

THE sixth annual convention of the National society will be opened in Boston in Potter Hall, the New Century Building, 177 Huntington Avenue, on Wednesday, June 10. At one o'clock the presentation of credentials, the registration of deleyates, and the payment of annual dues will be in order. At three o'clock the Kev. Ldward Everett Hale, D.D., will make the invocation.

The address of welcome will be delivered hy Mrs. Ednah D. Cheney, with a response by the president; the assembly will then be adjourned for an informal reception of delegates and visitors hy the officers.

Thursday, May 11.- Koll-call at half-after nine in the morning, and delegates should endeavor to he present at that time.

The secretary's report on behalf of the Executive Committee will be called for and followed hy the report of the treasurer. After these will come the reports of the committees, and one very important report will be that of the Constitu. tion Committee. The amended constitution, as proposed at the fifth annual convention, will come up for a final vote this year, and each delegate should be supplied with a copy of the old constitution, of the revised one, and of the fifth annual report; indeed, each delegate should have in her possession a copy of each of the five annual reports issued hy the Associated Alumnæ, otherwise she will find it difficult to follow the discussions.

Most interesting and inspiring will he the reports to he made officially, for the first time, from the five State societies-Illinois, North Carolina, New Jersey, New York, and Virginia.

The pupers for discussion will be upon "The Administration of Private Sanatoria," "The Duty of the Superintendent in Instructing the Pupil Nurse as to Her Duty to the School Alumnæ," "State Registration," "State Legislation," " Ethics," "The Working of a Registry," with several suggested topics for the "open meeting."

All nurses are cordially invited to the Associated Alumn» meetings whether memhers of an affiliated society or not.

Boston and its suhurhs offer much to the visitor at any time, and nurses should make an especial effort to combine the advantage of being present at a gathering representing about eight thousand of their profession and going over such historic ground. 
On Thursday evening a reception will be given to the officers, delegates, and their friends by the Nurses' Alumne Association and the Nurses' Club of the Boston City Hospital.

From eight to ten o'clock on Friday evening a dinner will be given to the delegates and officers by the Alumnæ Associations of Massachusetts.

Those wishing to arrange about stopping-places should write to the Bureau of Information, Boston Nurses' Club, 755 Boylston Street, or see list of hotels with rates as published in the May number of The American Journal of Nursing.

A reduction in transportation has becn secured, and delegates and visiting members ale asked to conforul to the directions for obtaining the certificate.

'Tickets at full fare for the going journey may be secured within three days, exclusive of Sunday, prior to the first day of the convention. Each purchaser of a ticket should ask the agent for a certificate- do not make the mistake of asking for a rcceipt. Certificates are not kept at all stations. If there should be none at the small station where the delegate is to board the train, she should be instructed to purchase a local ticket to the larger station, where she may obtain a through ticket and a certificate. In view of this contingency the wisdom of arranging for transportation two or three days in advance will be seen.

An agent of the railway company will bc in attendance the afternoon of June 11 to validate ccrtificates. No certificate can be validated except during the time the agent is at the Convention Hall, and unless the certificate is validated the holder is not entitled to any reduction on the return farc.

The committee will be glad to receive propositions that may be presented by any alumnic, and inforntation will be gladly supplicd upon requcst by the secretary, Mart E. Thornton, 120 East Thirty-first Street, New York.

\section{NEW YORK STATF, NURSES' ASSOCIATION}

THE second annual meeting of the New York Statc Nurses' Association was held in Albany on April 21, 1903.

The meeting was called to order at ten-fifteen A.M., the acting president, Miss Bailey, in the chair, who took occasion at this time to announce that the Armstrong bill, in which the association was so deeply interested, had passed the State Assembly the previous night hy a vote of one hundred and two to twelve. This statement was greeted with applause.

The secretary called the roll and read the minutes of the last meeting. which, after a slight correction. were approved as read.

The presiding officer announced that the order of the day would be the read. ing of reports of the different officers and committees, leaving the election of officers and other work until the afternoon.

Miss Brooks, the trensurer, read her report, which was approved.

The president reminded the members that some of then were still in arrears for the year 1903, and that the treasurer was very much in need of money.

The secretary read a report of the two years she had served during the life- . time of the association, showing the growth of the association and the work accomplished. The chair stated that this was certainly a very encouraging report. Upon motion this report was accepted.

Miss Maxwcll. chairman of the Committee on Credentials, not being present, her report was read by Miss O'Neill. This report showed that for the last 
quarter of the year, ending April 2I, applications have been reeeived for seventeen individual memberships and seven alumnæ associations, as follows:

The Alumnx Association of St. Mary's Hospital Training-Sehool for Nurses, Brooklyn, N. Y. Membership, thirty.

Alumna Association of the Training-Sehool for Nurses of the Roosevelt Hospital, New York City. Membership, sixty.

Alunine Association of the Kings County Hospital Training-Sehool for Nurses. Membership, thirty.

Alumnæ Association of the New York Hospital Training-Sehool for Nurses. Membership, two hundred and eighty-five.

Alumna Association of the Training-School for Nurses of the New York Post. Graduate School and Flospital. Membership, one hundred.

Alumne Association of the Brooklyn Homoopathic Hospital Training-School for Nurses. Membership, sixty.

Alumnar Association of Mt. Sinai Training-Sehool for Nurses, New York City. Membership, eighty-four.

Miss Carli Andersen, Fppendorf Ifospital, Hamburg, Germany, 1893, old Marion Strcet Hospital (Maternity), New York, 1887; Miss Edith H. Shay, Geneva City llospital, Geneva, N. Y.: Miss Ida B. Meeks, Amsterdam Hospital, Amsterdam, N. Y.; Miss Mary B. Soeti, City of Kingston Hospital, Kingston, N. Y.; Miss Mary A. C. Moore, Bellevue Hospital, New York City; Miss Susan I. MeGee, Amsterdam Ilospital. Amsterdan, N. Y.; Miss Agnes A. Douglas, Episcopal Flospital Training.School, Philadelphia, Pa. (post-graduate Boston Charitable Eyc and Har Infirmary); Miss Minnie Hilbert Gloor, Amsterdam Hospital, Amsterdam, N. Y.; Miss Evelyn Lee Messenger, 1883, Auburn City Hospital, Auburn, N. Y.; Miss Olive B. Barclay, 1001, Amsterdam City Hospital, Amsterdam. N. I.: Miss Sarah F. Ward, 1892, New lingland Iospital and Boston Lying-in, 1893; Illinois Training-School, 1897; Miss Jane H. Pindell, 1900, New York City Training-School. New York City; Miss Martha E. Bollerman, 1900, New York City 'Training-Sehool, New York City; Miss Flizabeth A. Olwell, Metropolitan Training-School, New York City; Miss Mary A. Houlihan, 1903, Metropolitan Training-School, New York City; Miss Sarah Isabel Hunter, 1902, Metropolitan Training-School, New York City; Miss Lillian E. Riley, 1896, New Jersey State Hospital, Morris Plains, N. J.

These assoeiations and individuals, having met all the requirements in the by-laws, were recommended to the association for further action.

List of applications recived and approved by Credentials Committee after March 1, 1903:

Alunnar Assoeiation of St. Luke's Hospital Training-School for Nurses. Membership, one hundred and one.

Alumna Association of the Brooklyn Hospital Training-School for Nurses. Membership, one hundred and two.

Alumna Association of the Training-School for Nurses of the German Hospital. Membership, seventy-seven.

Miss Agnes MeInnes, 1898, New Jersey State Hospital, Morris Plains, N. J.; Miss Eva V. Kay, 1898, Hahnemann Hospital, Rochester, N. Y.; Miss Helena Mills, 1902, Halınemann Hospital, Rochester, N. Y.; Miss Elsbeth H. Stahl, 1891, Methodist Episcopal Hospital, Brooklyn, N. Y.; Miss Caroline A. Dockstader, 1901, Amsterdam Hospital, Amsterdam, N. Y.; Miss Alma G. Clark, 1902, Hahnemann Hospital, Rochester, N. Y.; Miss Ida M. Wainwright, 1002, Hahnemann 
Hospital, Roehester, N. Y.; Miss Margaret E. Reynolds, 1902, Hahnemann Hospital, Roehester, N.Y.; Miss Lillian E. Bickle, 1902, Hahnemann Hospital, Rochester, N. Y.; Miss Maude L. Parks, 1001, Nathan Littauer Hospital, Gloversville, N. Y.; Miss Marie Schwartz, 1898, Nathan Littauer Hospital, Gloversville, N. Y.; Mrs. F. R. Fulton, 1903, Nathan Littauer Hospital, Gloversville, N. Y.; Miss Ruth A. Hathaway, 1900, Nathan Littauer Hospital, Gloversville, N. Y.; Mrs. Mary Weideman, 1899, Nathan Littauer Hospital, Gloversville, N. Y.; Miss Maude Granger 'lompkins, 1902, St. John's Training-Sehool, St. John's Hospital, BrookIyn, N. Y.; Mrs. Minnie J. Ledlie (John B.), 1902, the Johns Hopkins Hospital, Baltimore, Md.; Miss Helen M. Nixon, 1899, Metropolitan Hospital, New York City; Miss Evelyn Nixon, 1890, Metropolitan Hospital, New York City; Miss Bessie Sarah Palner, 1896, St. Luke's Hospital, Utiea, N. Y.; Miss Ida E. Thomas, 1898, Halınemann Hospital, Rochester, N. Y.

Total alumnce associations, three; individuals, twenty.

After a sliglit eorrection the report was approved as read.

Upon motion that the applications be voted upon as a whole and accepted by the socicty the motion was carried.

Miss Ida Palmer, chaimman of the Committce on Revision of By.laws, said all work done towards changes in the by-laws was in the hands of the secretary, who had sent copies of tle proposed amendments to each member and to the secretary of each organization.

In the absence of Miss Allerton, clairman of the Legislative Committec, who was ill and unalle to be present, the report was read hy Mtiss Cadmus as follows:

"It has been a year of great anxiety for all of us who realize what this bill means to us, nanely, making the art of uursing a profession. It seems a far cry from November, 1890, to April, 1903. The paper read by Miss Palmer before the Federation of Women's Clubs in November, 1809, on "Stnte Registration of Nurses," and supplemented by ine only becausc of lack of time for Miss Palmer to get the subject properly before the audience, was the beginning of any active work in this direction. We had a resolution prepared and passed by this body of women at this time favoring such registration. We then claimed that nurses should examine nurses, and that in no other way but by registration under the Regents eould the standards of training-sehools be clevated and the instruction be made uniform. The idea grew and the nurses beeame interested. Societies were formed. Then, two years ago, enme the State society, which has now fifteen hundred and nine members as trained nurses. One year ago we felt that we were in working order and began this strenuous work. The bill was given to Senator Armstrong, of Monroe County. In this work he has been most ably seconded by the Assemblymen from Monroe County, Mr. Martin Davis, Mr. Eugene Dwyer, Mr. G. H. Smith, and Mr. Pallaee. That they have worked faithfully against great odds you know. I will from here on submit the report of the proceedings as published by Tine American Journal of Nunsing. The Armstrong bill passed the Senate, but was not sent over to the Assembly until last week. It is now on the calcndar and eomes up for passage April 20. On April $9 \mathrm{Mr}$. Nye's bill for registration of nurses eame up for the third reading. We sueeeded in having it amended to eonform exaetly with the Armstrong bill. The amendment was earried by a large majority and the bill was sent back to be reprinted. We consider this eondition of affairs very favorable for the passage of the Armstrong bill, and hope at the time of reading this report the Governor will be ready to sign the bill. I wish to acknowledge ten dollars 
received from Dr. William S. Ely, of Rochester, and five dollars from Miss M. Louise Longeway, of New York, which was used for telephone and telegrams: I also thank the nurses and friends who have so loyally stood by us and held up the arms of the committee.

$$
\text { "April 15." (Signed) " Eva Allerton. }
$$

After being moved and seconded, the report was accepted as rcad.

Miss S. F. Palmer asked the privilege of the floor in order to speak a few words in regard to the work done by Miss Allerton for the society. She said Miss Allerton was a magniflcent leader and had been magnificently assisted by New York, Buffalo, Jamestown, and other places; that it had been found in coming to Albany to lobby that the work of individual nurses had told tremendously in this State.

A motion was made that we give Miss Allerton and her committee a vote of thanks.

This was amended by Miss Palmer to the effect that the secretary be illstructed to send Miss Allerton a telegram at the close of the session expressing thanks and appreciation of the members.

Seconded and carried unanimously by a rising vote.

The report of the Committee on Publication and Press was read and accepted.

Two of the trustees being present, they stated there was no report to make.

The Nominating Committee reported as follows: For president-Miss Rhodes, Miss Twitchell; for flrst vice-president-Miss Gardner, Mrs. A. Morgan; for second vice-president-Miss Keating, Mrs. Longenfelter; for sccretary-Miss Pindell, Miss McCallum; for treasurer-Miss Daniels, Miss Silver; for trustecMiss O'Neill, Miss Dall.

A motion was made by Miss S. F. Palmer and seconded by Miss Dock that the report be accepted. Carried.

The amendments to the by-laws then came up for discussion and were hy consent put over to the afternoon session.

Moved, scconded, and carried that we adjourn at twelve-thirty-five.

The afternoon scssion was called to order at one-thirty by the presiding officer, who read a telegram from Miss Allerton congratulating the association upon the passage of the Armstrong bill and expressing a hope that the members call upon the Governor; also one from Miss Damcr.

The work of amending the by-laws was then taken up, the result of which will be puhlished by the Committce on Revision of the By-laws.

Miss S. F. Palmer took the floor and said that she had a recommendation which was sent to her by Mr. Andrews, the lcgal adviser of the Legislative campaign, drawn by him, which, if Miss Allerton were present, would probably come from her. Miss Palmer stated that at the present time there was no clause in the by-laws by which a Board of Examiners might he selected, and this resolution was proposed as a proper way for the society to provide for this emergency until it could be provided for in the by-laws in proper form. The resolution was then read and presentcd to the society for consideration.

"Wriereas, The Senate and Assembly of the State of Ncw York have passed the Armstrong bill, being an act to amend the Public Health Law relative to the practice of nursing, and 
“Wnereas, It seems probable thut said act will soon reeeive Executive approval and become a law, and

“ Wheneas, Said act provides amoug other changes that the New York State Nurses' Association shall nominate ten nurses and present the names of said nominces to the Regents of the University of the State of New York; now, therefore, be it

“ Resolved, By the New York State Nurses' Association, that the Executive Committee be and the said committee hereby is empowered to select the said nominees and transmit their names to the secretary of the Regents."

A motion was made by Miss Thornton and seconded by Miss Stone that the resolution be adopted as read. Carricd.

After norc discussion and business connected with the by-laws, etc., the election of officers was taken up with the following result:

President, Miss Annic Rhodes, 202 West Seventy-fourth Street, New York.

First vice-president, Mrs. A. Morgan, Lincoln Hospital, New York.

Second vice-president, Mrs. Lingenfelter, Amsterdam Hospital, Amsterdan. Secretary, Miss McCallum, Post-Graduate Hospital, New York.

Treasurer, Miss Silver, New York City Training-School, New York.

Trustee, Miss O'Neil, Kings County Hospital, Brooklyn.

It was moved and scconded that the same chairmen of all committees be retained for the couning year.

Miss Palner declining to serve on the Conmittee on Publication and Press, Miss stone was elected to till her place.

One special committee-on Resolutions-was added and Miss Thornton was chosen as chairman.

Thrce meinbers of the Executive Committee were elected from the floor, Miss MeKinnon, of Buffalo; Miss MeDermott, of Utica, and Miss Lord, of Albany.

After a vote of thanks was given to each of the retiring ofliccrs the meeting adjourned to reconvene in New York City the last Tuesday in October, 1903.

ELizabetil C. Saniond, Secretary.

\section{ORDER OF SPANISH-AMERICAN WAR NURSIS}

Tne annual meeting of the Spanish-American War Nurses will this year be held in San Francisco, Cal., on August 21, 1903, thus taking advantage of the Grand Army of the Republic rates on the railways and getting to San Francisco after the G. A. R. has left that city. It is planned for the tourist agents, Summons \& Marsters, of Boston, to take charge of the entire trip. The cost from the Atlantic coast will be one liundred and twenty-two dollars, and will include cyerything, from residence to San Francisco and bnck. For two in one lerth the cost will be one hundred and fifteen dollars. Members living near San Francisco will have lower rates. Ample facilities for making tea and coffee and cooking simple food will be provided on the train. Stops will be made at Denver, Colorado Springs, GIenwood Springs, Salt Lake City, and otler points, with opportunities for side trips to Garden of the Gods, Pike's Peak, etc. Two days will be spent in San Francisco, where trips are planned by resident mem. bers. Return trip over southern route stops in Los Angeles, San Jose, and Santa Barbara. Route through the great Mojave Desert, stop at Laguna, N. M., to visit Pueblos of Moki Indians. Arrive in Chicago on Monday, August 31, at ten P.M. 
Members of the Spanish-American War Nurses are at liberty to bring any friends they wish with them.

For partieulars address Simmons \& Marsters, No. 26 Sehool Street, Boston, Mass., or Mrs. George Lounsbery, treasurer Spanish-Ameriean War Nurses, Charleston, W. Va. Fuller particulars will be published next nontl.

\section{A NEW ASSOCIATION}

A meeting for the purpose of organizing a Pennsylvania State Nurses' Assoeiation will be held on Monday and lucsday, June 8 and 9 , in the Hall of the Collcge of Physicians, soutlieast corner of Locust and Thirteenth Streets, Philadelphia.

The neeting will be called at ten A.s., Monday, June 8. An effort will be made to have the busincss finished in time to enable those who desire to attend the Convention of the Associated Alumnx in Boston, June 10.

All alumne associations, nurses' clubs, and schools liaving no organized association are earnestly repuested to send delegatcs.

All resident graduatc nurses in the State of Pennsylvania are invited to be present and take part in the discussions.

The ultimate object in organizing a State society is to secure legislation for the advancement of the nursing profession.

A. E. Brobson,

J. H. MORLAND,

L. ALLEN,

Committee on Circular.

\section{TILE PUBLIC SCHOOL NURSING IN NEW YORK}

Miss Ada M. Cranke, of St. Mary's Hospital, Brooklyn, laas been appointed on the service in place of Miss Myer, resigned, and Mrs. H. O. Whitehill, of the J Long lsland College Hospital, has been appointed in place of Miss Chappelle, resigned.

The knowledge of the l'ublic Sehool Nursing is arousing general interest, requests for detailed information having come from points as remote as California, Virginia, Cuba, and many plaees nearer lonc.

A German physician visiting the eountry cane lately to investigate the medi. cal inspeetion and the nursing serviee in the sclools and was much interested, und on May 7 Dr. Lederle, Health Commissioner, and Miss Rogers, Supervising School Nulke, went to New Haven on invitation of the Fastern Edueational Assoriation to speak upon the work and the bearing it has upon the edueation of the child.

L. I. R.

\section{TIIE OFFICIAL AXE FALLS}

Chicago.-Governor Yates has attached his veto to the "Nurses' Bill." The bill provided for the examination. registration, and licensing of nurses and for the regulation of institutions which graduatc or eonfer degrees or diplomas on nurses by the State Board of Health. In explaining his reason for vetoing the bill Governor Yates says:

"I veto this bill beeause I do not believe there was due deliberation in its eonsideration and passage, and beeause it is not comsistent with the general policy of the constitution." 
One of the chief objects set out by the Governor is the provision for examination. On this subject be says:

"It has been proposed that a State Board of Nursing Examiners be appointed by the Governor from a list of nominations subnitted by the State Nurses' Society. If the tendency is not checked it soon will be proposed that the AttorneyGeneral be required to appoint the Assistant Attorney-General from a list of nominations presented by tbe State Bar Association. In other words, tbere seems to be a decided tendency towards 'governnent by society,' which is as objection. able as any otber kind of government not recognized by the constitution."

\section{REGULAR MEETINGS}

New York. - The first annual meeting of the Association of Graduate Nurses of Manhattan and Bronx was held on May 5 in the lecture-room of the League for Political Education. 'The meeting was very well attended. The ninutes of the last meeting were read and approved. The report of the secretary gave evi. dence of increasing interest in the association by the New York nurses. The treasurer's report showed a balance, when all the expenses of the year were paid, of twenty-two dollars and eighty-three cents. The leport of the delegates to the Nurses' State Association, held in Albany last month, was heard with intel'est.

This association desires to bring before the New York nurses the reason for its existence, and also particularly its objects, viz.:

"To aid in securing State legislation and registration. to elcrats the professional standard, and to cultivate and cherish a feeling of good-fellowship annong the members."

Two years ago, wlıen the New York State Nurses' Association was organized, with the primaly object of securing State legislation for the uursing profession, its by-laws relating to eligibility and membership stated that all resident nur'ses of the State meeting these requirements were eligible for membership; also that its members should be delegates from organized local associutions of nurses and individual nurses, such individuals to be asked to organize when they sloould lave reached twenty-five in a county.

At that time the only organized local associations existing werc the alumme associations of the various training-sehools. These, of course, included only their own graduates. There still remaincd a large body of nurses not belonging to the alumnæ associations who were resident in the State and engaged in private practice and institution work who could have no voice nor representation in the State association except through individual nembership.

Believing in organization and the advantages to be gained by unity of thought and purpose, the Association of Graduate Nurses of Manhattan and Bronx was organized in New York City to include all gradunte nurses in good standing resident in Manhattan and Bronx not connected with any other local association. This association loas the same eligibility clausc as the State association and practically tbe same objccts as the alumna associations. It has now at the end of its first year forty members on the roll. At the last meeting of the State associa. tion it was admitted to membership in that body. and will send to the next meeting in Albany this month three delcgates who will earry with them the votes of its member's, thereby having a voice in the affairs of the State association equal to that of the alumna associations.

During the past winter the association has united with the Associated 
Alumnæ of the city in an arrangement with the League for Political Education for a course of lectures especially planned for nurses on " Civil Government," "Sociology," "Current Events," etc., allowing its member's to uttend the course at a moderate cost.

It is hoped that during another year the menbership will be greatly increased and that there will be a decided advance along educational lines and in social intercourse, and we trust many nurses who have not thus fur been especially interested may consider more seriously the objects of the association and join with us.

Blank forms for application can be had by writing to the secretary.

At the annual meeting the Membership Committee had a list of twenty upplications for membership. Nineteen of these were approved, one was held for further consideration, and eight applications were received too late to be acted upon this month. 'The following are the officers elected for the year': 1'resident, Miss McKeclnie; vice-president, Miss Kirschoff; secretary, Miss Bussell; treas. urer, Miss Carson. The three trustees elected are Miss Maxwell, Miss Daniels, and Miss McCallum. A vote of thanks was given to the retiring officers, Miss Spring-Price and Miss Wakefield. The rapid increase in nembership during the past six months has been very satisfactory, and the association has every reason to feel assured of success in its future.

Nkw Yokk.-The members of Camp Roosevelt, Spanish-American War Nurses, met at the club-rooms, 155 East Eighty-third Street, on Monday, May 4, ut three r.M. The meeting was presided over by Captain Saunders. The minutes of the last meeting were read and approved of. Reports from the Committees on Jy-laws and Finances were postponed until Junc. A letter was rend from Mr's. Lounsbery in which she spoke of the proposed trip to San Francisco in August of the Spanish-American War Nurses at the same time that the Grand Army of the Republic has its excursion, and hoped to be able to secure for us very inoderate rates and stopovers in different cities en route. Mrs. Lounsbery begs all members of the society to send her at once their correct addresses. A letter of greeting from Miss Wilson, the general recording secretary of the order, was read. Miss Wilson urges all members to take an active interest in the association and congratulates "Camp Roosevelt" on its successful start. A motion was carried that all member:s of the Spanish-American War Nurses who apply for membership in Camp looscvelt wear their badge of the order, as there are only two requirements necessary for joining-namely, the puyment of the dues and the fact of belonging to the Spanish-American War Nurses' Association. A vote of thanks was tendered Dr. MeGee for the pleasure derived from the reading of the pamphlets which she sent us, and we trust that we shall again be so favored. The many friends of Miss Esther Hasson will deeply feel for her in the death of her brother. A letter of sympathy has been sent her froin Cainp Roosevelt, of which she is a charter member. When all business on hand had been attended to the remuining hour was spent in the telling of anecdotes and reminiscences of camp life. The next meeting will take place on Monday, June 1, at three P.M., at the usual place.

BrookLys,-The annual meeting of the Alumna Association of the Methodist Episcoopal Hospital Training-School was held at the Methodist Episcopal Hospital on April 8, Miss Waterman in the chair. After the regular business the result of 
the election was announced by thc chairunun of the Nominating Committee and was as follows: President, Miss L. Waterman; first vice-president, Miss $M$. Seward; second vice-president, Miss O. Shipman; treasurer, Mrs. A. Prentis; secretary, Miss Edna Copeland. Standing committees, appointed by the chair, were as follows: Credentials Committee-Miss Frost, Miss Stoney, and Miss Ferris; Educational Committee-Miss Ida Hall, Miss De Witt, and Miss Shipman; Social Comnittee-Mrs. Calkins, Miss Hope, Miss Gaskin, Miss Ellis, and Miss Stubenrauch. Miss Smith and Miss Treganza were proposed for membership. There was an informal discussion of the reception to be tendered the graduating class of the Methodist Episcopal Hospital Training-School. An interesting letter from Miss.Hall, supervisor of the General Hospital, Seattle, Wash., former supervisor of the Methodist Episcopal Hospital, was then read and very much enjoyed. Miss Hope and Miss Shipman were appointed to respond to this letter. 1)r. Kavanagb, superintendent, and Miss Hurd, supervisor, of the Methodist Episcopal Hospital, were proposed for honorary membership and unanimously elected. The association procecded to elect a delegate to the annual convention of the Associated Alumna to be held in Boston. Miss Waterman was elected, and Miss Richards and Mrs. Prentis as alternates. Meeting adjourned.

BrookLys.-The annual inceting of the Long Island College Hospital Alumnæ Association has just been held, Miss Davids, the president, in the chair. The usual annual reports were read, approved, and suggestions adopted. The following persons were duly appointed the ofticers for the coming year: President, Miss Davids; first vice-president, Miss Nelson; second vicc-president, Miss A. Wilcy; recording sccretary, Miss L. M. Sargent; corresponding secretary, Miss C. Hall, 163 Congress Street; treasurer, Miss Burdick, 128 Pacific Street, Brooklyn; secretary and treasurcr of the Sick Fund, Miss E. G. Brown, 683 Flatbush Avenue. The Executive Committce are Miss E. Hall, Miss J. E. O'Daly, Miss S. M. Nelson, Miss C. Arnold, Miss S. M. Johnson. On April 17 a progressive euchre was held at the Pierrepont Assembly rooms for the benefit of the ncw registry for graduate nurses of the Long Island College Hospital Training-School, which proved a great success. A large number of prizes were donated, as well as a very liberal supply of refreshments. The proceeds realized over three hundred dollars. The register and club was opcned on May 1, under the superintendence of Miss $\mathbf{S}$. $\mathbf{M}$. Nelson, and is now in full operation in providing nurses. The major part of the rooms have already been taken up.

BaLtimone.-The regular meeting of the University of Maryland Nurses' Alumnæ was held in the reception-room of the hospital on March 26, 1903, at four P.M. Dr. Anita Newcomb McGee, president of the Spanish-American War Nurses' Association, addressed the members on army nursing during the Spanish-Ameriean War. The address wus very interesting and thoroughly appreeiated by all present. After the meeting adjourned Mrs. Taylor, superintendent of nurses, kindly served refreshments in the form of tea and cake. Dr. McGee was escorted through the hospital and Nurses' Club, 21 North Carey Street. She seemed specially pleased with the Nurscs' Club. The University of Maryland Nurses' Alumnæ will always remember Dr. McGee as a friend of the army nurse. A special meeting of this association was held Wednesday, April 15, 1003, at four P.M., at the Nurses' Club, 21 North Carey Street. The object of the meeting was the election of delegate for the convention in June to be held in Boston, Mass. Miss Eleanor Mayes was elected. 
Chicago.-The regular montlly meeting of St. Luke's Alumnæ Association was held on Wednesday, April 15, at three P.M., at the hospital. Preeding a most delightful and interesting talk on food values, given by Mrs. Norton, of the University of Chicago, a short business session was held. Six new names were presented for membership. The report of the Programme Committee was taken up, giving an almost full outline of proposed work for next year. A motion was carried that the acceptance of the progranme be voted upon at the annual meeting in June. A motion was also carried to call a special meeting on Wednesday, April 29, to detcrmine the pleasure of this association regarding the proposed changes in the constitution of the National Association. At said special meeting there was an unusually large attendance, and the matter in hand was thoroughly discussed and well considercd. This association strongly advocated the threeyear training limit for eligibility to membership in the National Association.

Erie Countr Alums w.-The Erie County Hospital Alumne Association met on May 6 with the nurses at 344 West Avenue. The regular routine business was transacted. The association decided to pay five dollars towards the reports of the Congress leld in Buffalo in 1901, for which they will receive four copies. Miss Emma J. Kcating was appointcd a delegate to the Boston meeting in June; Miss Ellen Mullett alternate. Miss McKinnon, president, gave the report, as delegate, of the New York State Nurses' Assoeiation meeting held in Albany in April, and at the close of her renarks it was decided that the association pay a share of the expenses incurred in the passagc of the "Nurses' Bill" through. the Legislature. The association accepted an invitation from Mrs. Welsh to mect at her home, 550 Main Street, Niagara Falls, N. Y., next n isk at four-forty-five P.M. to meet the first Wednesday in June.

Philadelphia.--The gráduate nurses of the Jewish Hospital have for'ned an Alumnæ Associntion with Miss McCoy as president; ${ }^{-}$. the, first vicepresident; Mrs. Tyre, second vice-president, and Miss Halsey ${ }^{*} \%$ sceretary and trensurer. The mectings will be held in the lecture-room of the hospital on the first Tuesday afternoon in each month at three P.M. by courtesy of the hospital managers. The graduates are scattered and some addresses cannot be found, but certainly all will want to join in making the alumnæ a success. Those who have not received notice of the same, please send name and address at once to the secretary, Miss Rebeeca R. Halsey, 6043 Main Street, Germantown, Philadelphia.

Gloversville, N. Y.-The annual meeting of the Nathan Littauer Hospital Alumnæ Association was held at the hospital on April 30. Officers were clected for the coming year and a light literary programme planned. The "Past Year's Work," which consisted of short papers on diseases and nursing topics, was very bencficial, and was much enjoyed by the members. Answering the roll-call with a current topic or suffering the penalty of paying a fine has added somewhat to our sick fund.

BrookLYN.-The regular monthly meeting of the Brooklyn Hospital Alumnæ was held at the Training-School on Tuesday afternoon, May 4, and was unusually well attended, thirty-two members being present. The question was again brought up and discussed as to the ways and means of raising money for an endowment fund. It is earnestly hoped that every member of our alumnæ will give or try to raise fifty dollars or more if possible during the coming year towards that fund. 
Portland, ME.-A regular monthly meeting of the Aluminæ Association of the Training-School for Nurses of the Maine General Hospital was held at the committee-room of the hospital on May 6 at eight P.M. After the business meeting four members were elected and three nore names proposed, after which a very interesting paper on epilepsy was read by Dr. Jane Lord Hersom. The meeting then adjourned until the first Wednesdny in June.

Deтrorr.-The Farrand Training-School Alumnx Association held its regular monthly mecting to-day, which was followed by a social meeting, during which some selections hy a prnfessional elocutionist were given. Refreshments were then served, the tablc looking vcry pretty. The occasion was so thoroughly enjoyed that the nembers decided on frequent repetitions.

Boston.-A meeting of the graduate nurses of Massachusetts is appointed to take place at four P.M., Junc 11, at Potter Hall, 177 Huntington Avenue, Boston. The purpose of the meeting is to complete the organization of the State Asso. ciation and to consider any other business that may properly come before the association. A full attendance is desired.

Lebanon Hospital, NEw York.-The name of the treasurer of the Alumne Society, Miss Estelle Nesbit, was inadvertently omitted in the report of lnst month.

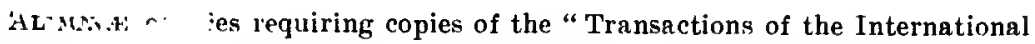
Congress nf Nirses" are to apply to Miss M. M. Riddle, 745 Massachusetts Avenue, Bosiun.

THe Commu lie Course in Hospital Economics begs to acknowledge ten dollars reci ! from Dr. J. S. Cook, of Buffalo.

Tre Editnr's address for the summer is Forest Lawn, Monroe County, N. Y.

\section{MARRIAges}

"Bell-Sneatn.-At Penetanguishenc, on April 22. at the residence of the bride's father, Mr. Alfred Sneatl, by the Rev. Chas. F. Perry, brother-in-law of the bride, Miss Martha A. Sneath and Andrew James Bell, professor of Latin in Victoria College, Toronto." Mrs. Bell is a graduate of the Torontn General IIospital Training-School, Class of 1894. Mr. and Mrs. Bell sailed for Europe on April 29, where they will spend the summer months. They will reside in Toronto.

ON March 17, 1903, by the Rev. Dr. Ningle, of St. Paul's Protestant Episcopal Church, Atlanta, Ga., Miss Blight, graduate of the University of Maryland Training-School for Nurses, Class of 1901, to Mr. Frederick Chambers. Mr. and Mrs. Frederick Chambers have gone to Montgomery, Ala., tn reside.

Miss Gertrude Wiggrss. a graduate of St. Iukc's Hospital, St. Paul, Minn., Class of 1899, was married on Wednesday, April 29, 1903, to Dr. Judd Goderich, at Duluth, Minn. At lome after September 1, 300 Goderich Avenue, St. Paul, Minn. 
AT Fort Defiance, Va., on January 15, Miss Rosabelle Perkins to Mr. Ernest Keesee, both of Virginia. Mrs. Keesee is a graduate of the Class of 1900 of the Old Dominion Hospital Training-School of Richmond, Va.

At Richmond, Va., on April 3, Miss A. W. MeClung to Mr. George Gibson, of Richmond. Mrs. Gibson is a graduate of the Class of 1899 of the Old Dominion Hospital Training-School of Richmond, Va.

At Elmira, N. Y., April 29, Miss Katherine Agnes White, Class of 1898 of Williamsport (Pa.) Hospital Training-School, to Mr. L. Cromwell Crowe, of Philadclphia.

\section{OBITUARY}

AT the monthly meeting of the Long Island College Hospital Alunınæ Association, held on Tuesday, May 12, the following resolutions wcre adopted:

"Whereas, Since our last meeting it has pleased God in His all-wise providence to take away by death one of our much respected members in the person of Miss S. M. Barkhausen, of the Class of 1889 :

"Resolved, To tender to her brother and friends the expression of oul association's deepest sympathy with them in their bereavement, and that we all very sincerely feel the loss of our beloved sister, who was a eredit to the nursing profession, in which she has done valued service during the fourteen ycars she was a member of it.

"Resolved, That a copy of the above be sent to Tie American Journal of Nunsing and a record of the same entered on the minutes of our society's meeting.

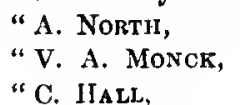

"C. IJALL,

"Committce."

AT her home in Bayonne, N. J., April 20, 1903, Eleanor B. Dower, graduate of the Newark City Hospital, Newark, N. J., Class of 1900.

Miss Dower gave promise in her training of a superior nurse. Direetly following her graduation she took a position as night nurse in the Nyack Hospital, Nyack, N. Y., which position she held with eredit to herself and the institution for over two years. Her influenee was one of cheerful refincment. This, combined with conscientious faithfulness in her work, won the respect and appreciation of all with whom she came in contact, particularly her patients, and many are the lives to-day that are better for her watchful eare and gentle influence.

Clara Hobrigan Devilin,

Ex-Superintendent Newark City Hospital Training-School, Newark, N. J.;

Gertrude Montfort,

Superintendent Nyack Hospital, Nyack, N. Y. 